Nikola Bajić ${ }^{1}$, Darko Veljić ${ }^{1}$, Marko Rakin ${ }^{2}$, Slobodan Stojadinović ${ }^{3}$, Jasmina Pekez ${ }^{3}$, Mihailo Mrdak ${ }^{4}$

EKSPERIMENTALNA LABORATORIJA ZA RAZVOJ DODATNIH I POMOĆNIH MATERIJALA ZA ZAVARIVANJE I LEMLJENJE

\title{
EXPERIMENTAL LABORATORY FOR DEVELOPMENT OF FILLERS AND AUXILIARY MATERIALS FOR WELDING AND SOLDERING
}

NASTAVAK IZ PREDHODNOG BROJA

2. deo

\section{CONTINUED FROM PREVIOUS ISSUE}

part 2
- Eksperimentalna oprema za razvoj i proizvodnju univerzalnog aglomeriranog praška za zavarivanje EPP postupkom
- Experimental equipment for development and production of universal agglomerated powders for submerged arc welding
Tehnološka oprema pruža mogućnost razvoja i proizvodnje novih pomoćnih materijala oblika granulisanog praha za navarivanje EPP postupkom. Zavisno od oblika komponenti za proizvodnju granulsanog praha potrebna je odgovarajuća priprema da bi se dobio oblik praha čije čestice imaju krupnoću od $0.06-0.25 \mathrm{~mm}$. Priprema komponenti sadrži tehnološke faze sušenja, mlevenja i prosejavanje koj se izvode na sledećoj laboratorijskoj opremi:

- $\quad$ sušenje se izvodi u komornoj sušari, slika 7-a

- $\quad$ posle sušenja izvodi se mlevenje komponenti na mlinu sa kuglama, slika 7-b;

- nakon mlevenja komponente se prosejavaju na vibro situ (slika 7-c) i čestice imaju krupnoću od $0.06-0.25 \mathrm{~mm}$.

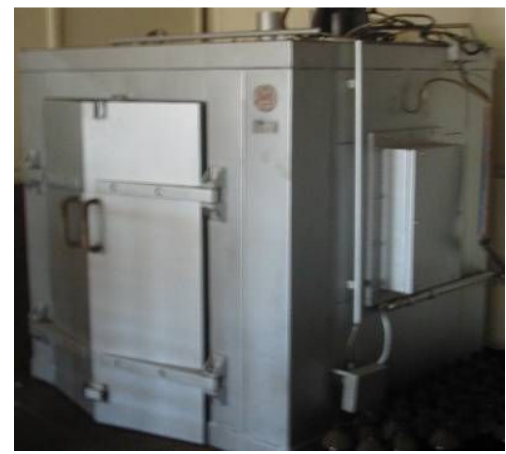

a)

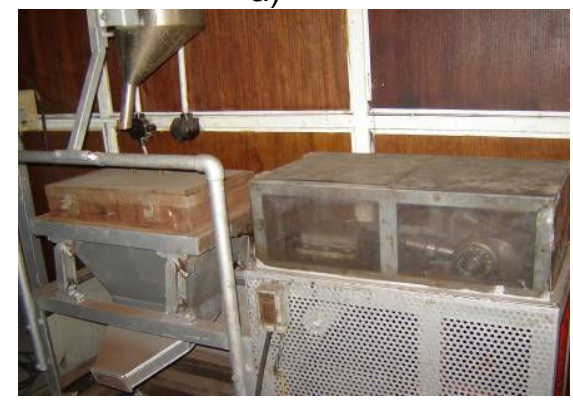

c)
Technological equipment enables the development and production of new auxiliary materials in forms of granulated powders for submerged arc welding. Depending on the type of components for producing granulated powders adequate preparation is required to achieve the form of powder with particle size from 0.06 to $0.25 \mathrm{~mm}$. Preparation of components includes technological stages of drying, grinding and sifting which is performed on the following laboratory equipment:
- drying is carried out in the drying chamber, Figure 2-a

- $\quad$ after drying the components are ground in a ball mill, Figure 2-b;

- $\quad$ after grinding the components are sifted through a vibrating sieve (Figure 2-c) to obtain a powder with particle size from 0.06 to $0.25 \mathrm{~mm}$.

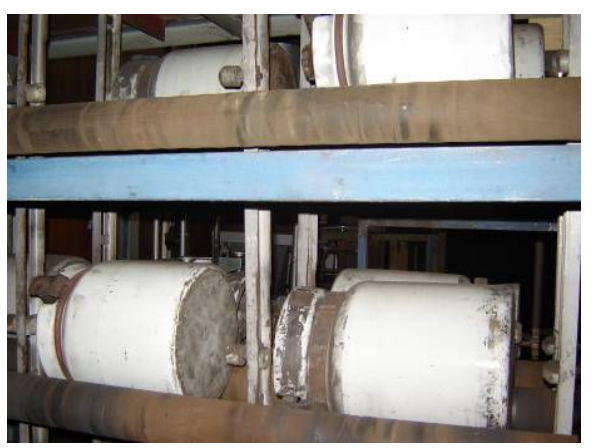

b)

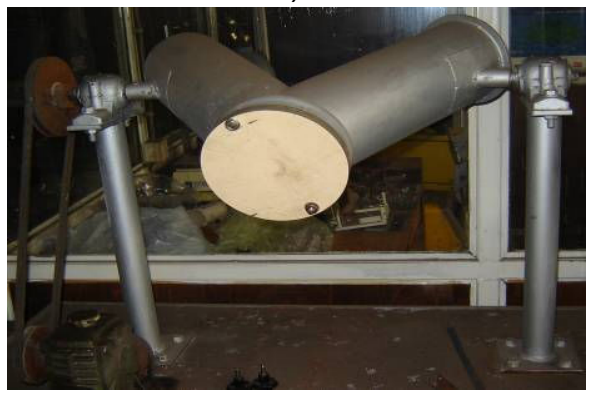

d)

Slika 7. Tehnološka oprema za pripremu komponenti praha $(a, b, c)$ i homogenizaciju mešavine (d)

Figure 7 Technological equipment for preparation of the powder components $(a, b, c)$ and mixture homogenization (d) 
Posle komponovanja i homogenizacije mešavina se dodaje u mikser sa vezivom,slika $8(a, b)$ nakon čega se izvodi prosejavanja krupnih čestica kroz sito otvora $3 \mathrm{~mm}$.

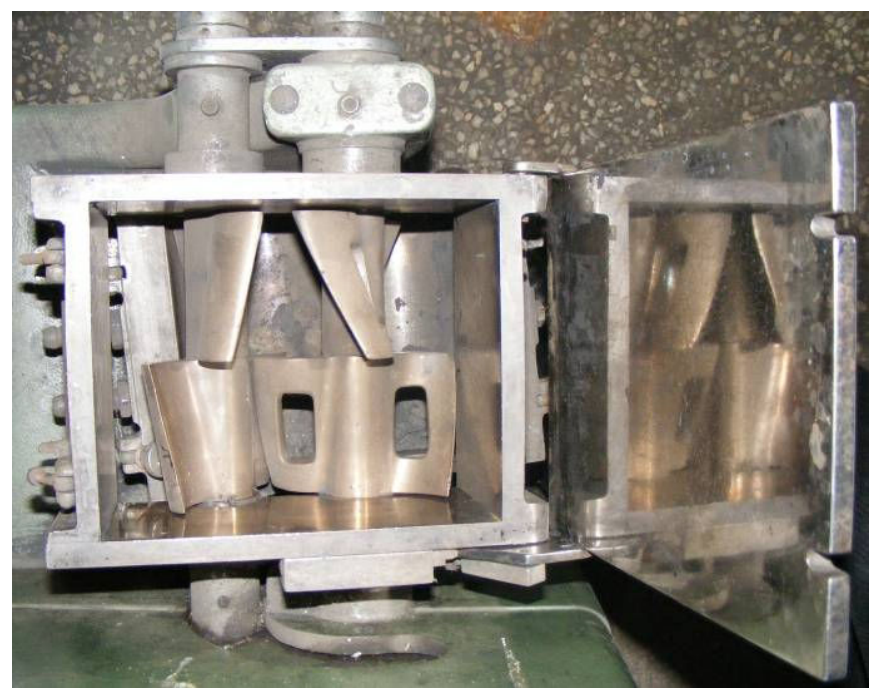

a)
After compiling and homogenization, the mixture is added to the mixer with the binder, Figure $8(a, b)$ after which the large particles are sifted through a sieve with $3 \mathrm{~mm}$ holes.

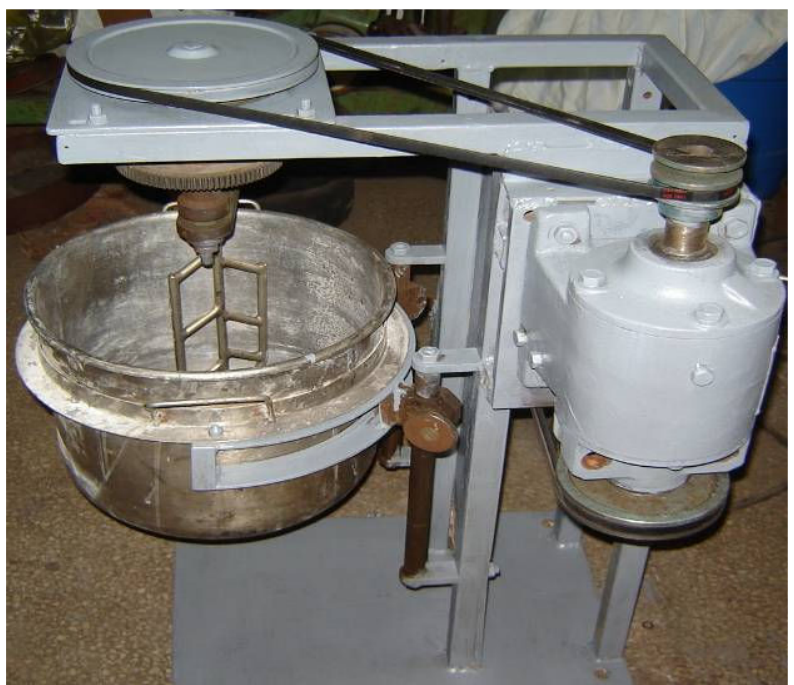

b)

Slika 8. Tehnološka oprema za formiranje mešavine praška i veziva $(a, b)$

Figure 8 Technological equipment for compiling a mixture of powder and binder $(a, b)$

Prosejana mešavina primarnog granulata dolazi na operaciju gde se izvodi finalna granulacija u granulatoru, slika 9(a,b). Uzorak se prosejava kroz sito otvora $3 \mathrm{~mm}$, da se odstrane krupne čestice, zatim se meri i kontroliše nasipna težina i po dobijanju odgovarajuće nasipne težine, granulat se prosejava kroz sito $2,0 \mathrm{~mm}$ i $0,45 \mathrm{~mm}$. Sitna frakcija se ponovo vraća u mikser i ponavlja čitava operacija granulacije [8].

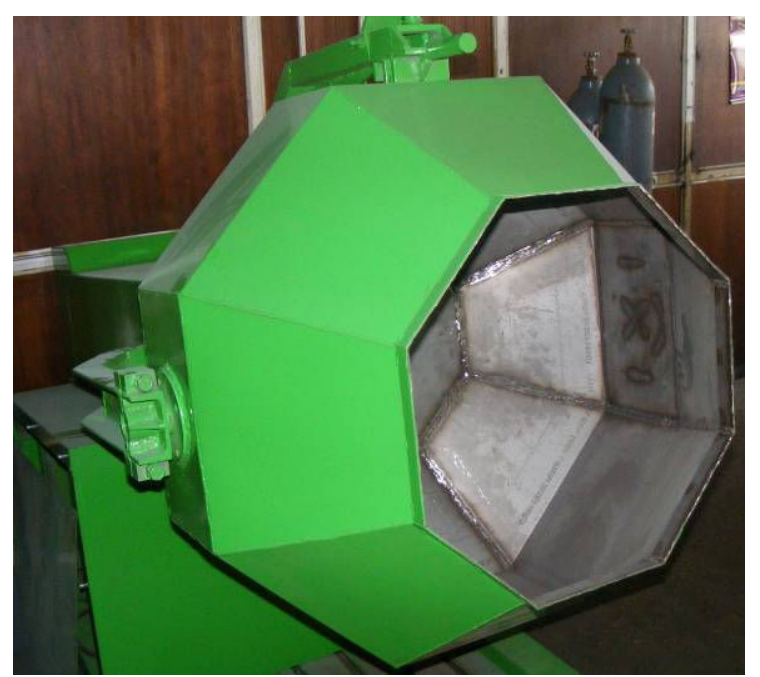

a)
The sifted mixture of the primary granules enters the process of final granulation performed in the granulator, Figure $9(\mathrm{a}, \mathrm{b})$. The sample is sifted through a $3 \mathrm{~mm}$ size sieve to remove large particles then it is measured and the bulk weight controlled. After getting the adequate bulk weight the granules are sifted through $2.0 \mathrm{~mm}$ and $0.45 \mathrm{~mm}$ size sieve. The fine fraction is returned to the mixer and the whole process of granulation is repeated [8].

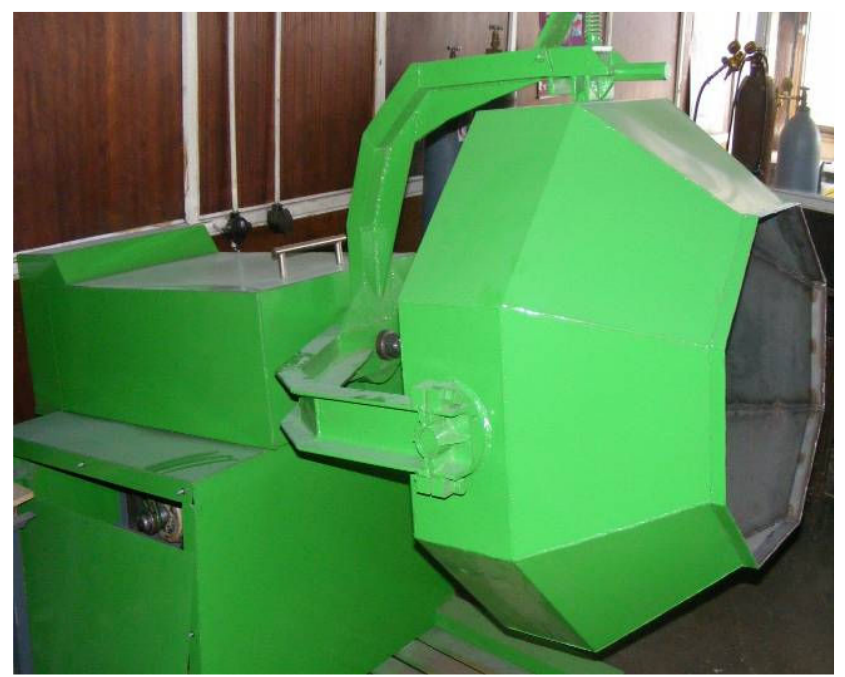

b)

Slika 9. Granulator

Figure 9 Granulator 
Posle granulacije mešavine i prosejavanja izvodi se sušenje granula praška a zatim aglomeracije odnosno pečenja koje se izvodi u elektropeći, slika 10(a), dok je izgled uzoraka dobijenog granulata dat na slici 10(b).

Nakon aglomeriranja prašak se prosejava gde se odvaja sitna frakcija dok se aglomerirani prašak odgovarajuće granulacije pakuje u džakove.

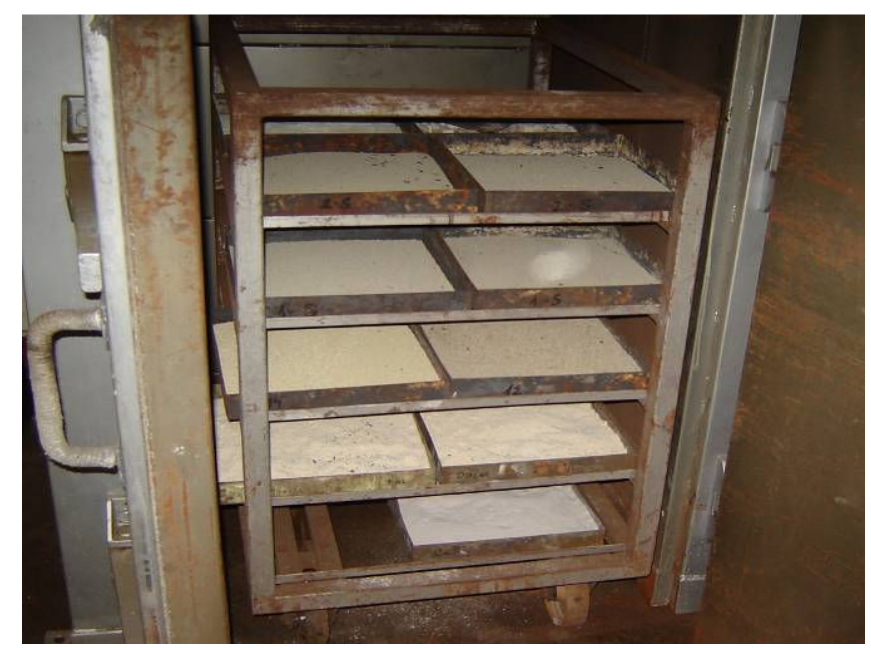

a)
After granulating and sifting of the mixture the powder granules are dried and then agglomerated i.e. baked in an electric furnace, Figure 10 (a), and the appearance of the produced granules shown in Figure 10 (b).

After agglomeration the powder is sifted, this separates the fine fraction while the agglomerated powder with suitable granulation is packed in sacks.

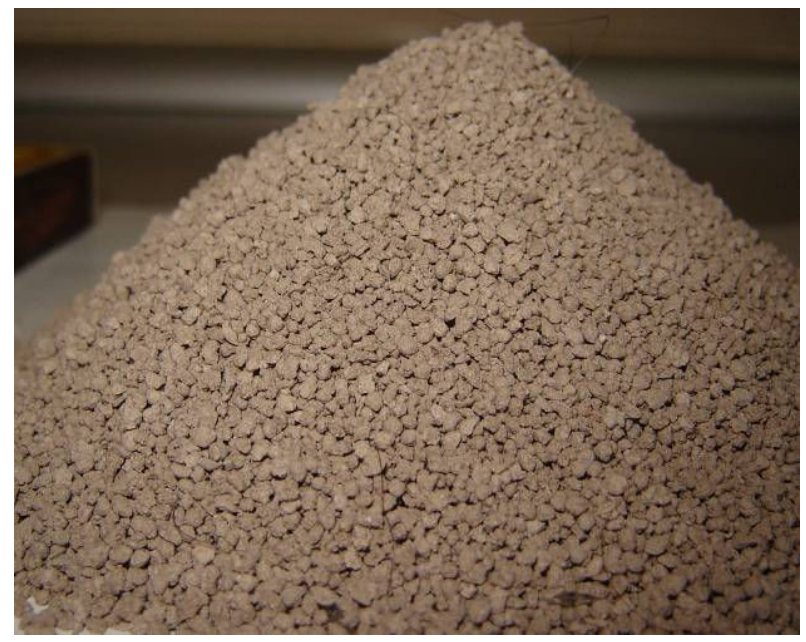

b)

Slika 10. Sušenje i aglomeracija granulata u elektrootpornoj peći (a) i dobijeni granulat praška (b)

Figure 10 Drying and agglomeration of granules in an electric resistance furnace (a) and the granulated powder (b)

\section{Eksperimentalna oprema za zavarivanje:}

Eksperimentalna laboratorija raspolaže opremom za zavarivanje slika 11 (a) koja omogućava da se proizvedeni dodatni materijal ispita $u$ pogledu zavarivačkih osobina.

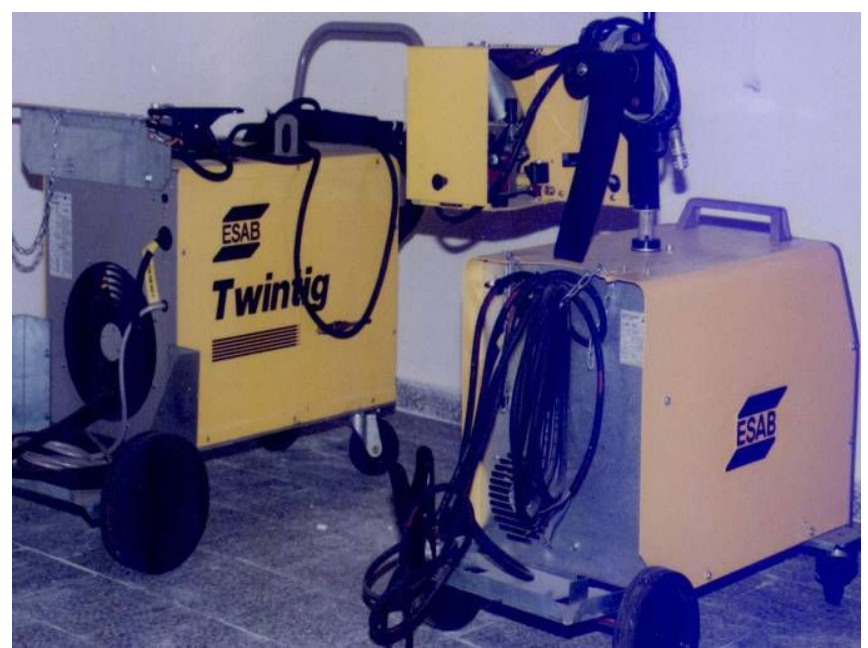

a)

\section{Experimental welding equipment :}

The experimental laboratory has welding equipment Figure 11 (a), which allows the welding characteristics of the produced filler to be examined.

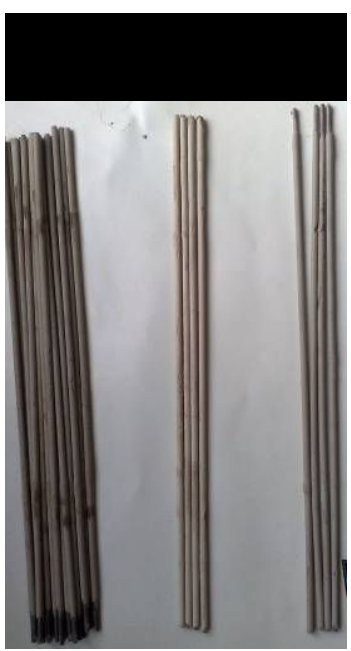

b)

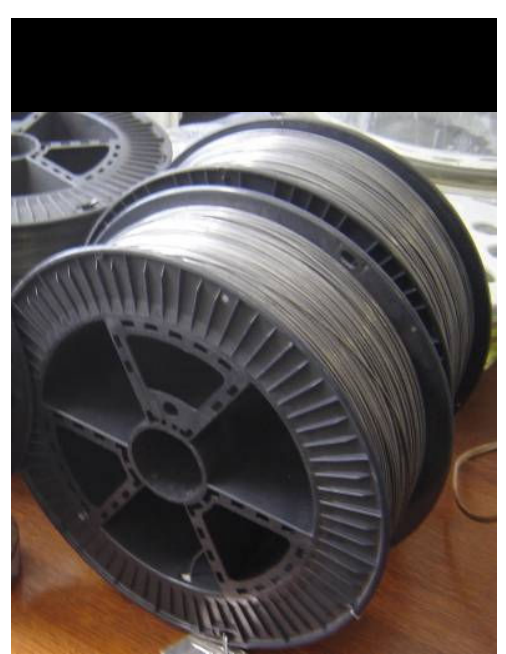

c)

Slika 11. Uređaji za eksperimentalno zavarivanje MIG/MAG, TIG i E-postupkom(a) u Istraživačko Razvojnom Centru IHIS Beograd i dodatni materijali oblika obložene elektrode (c) i punjene žice(b)

Figure 11 Apparatus for experimental welding using the MIG / MAG, TIG and E-process (a) in the Research and Development Center IHIS Belgrade and filler in the form of a coated electrode (c) and cored wire (b) 
Izvođenje elektro lučnog ručnog zavarivanje (a) novom obloženom rutilnom elektrodom (b) se vidi na slici 12(a)., a MAG postupkom punjenom žicom se vidi na slici 12(b)

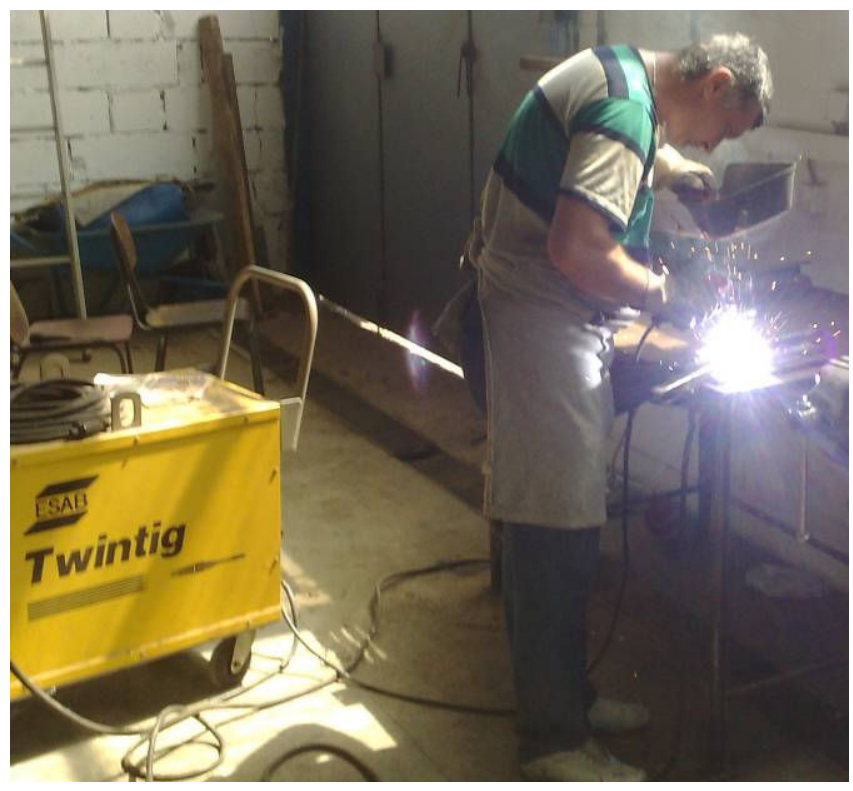

a)
Performing manual electric arc welding (a) with a new coated rutile electrode (b) is shown in Figure $12(a)$, and using the MAG process with a cored wire is shown in Figure 12 (b)

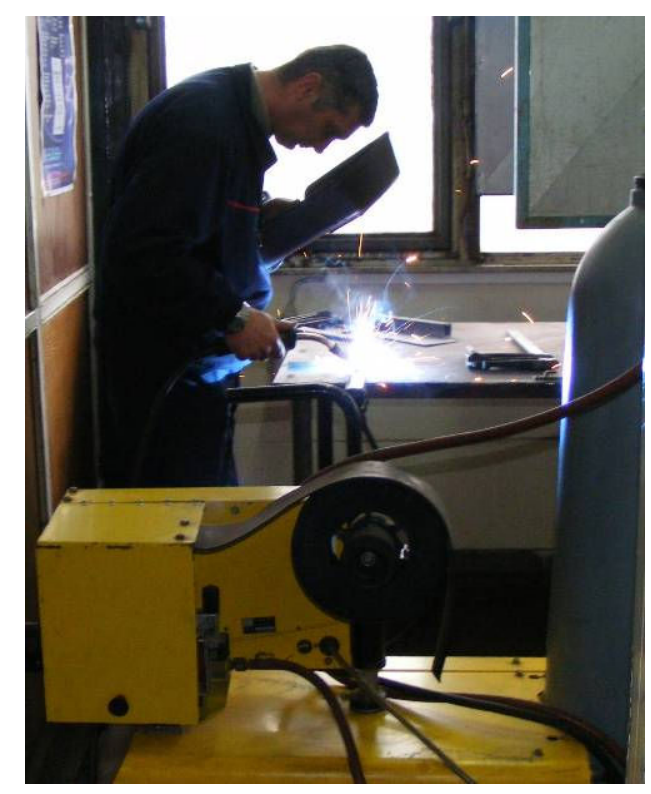

b)

Slika 12. Zavarivanje E-postupkom (a) obloženom elektrodom i MAG postupkom (b) punjenom žicom Figure 12 E-welding process (a) with a coated electrode and the MAG process (b) using a cored wire

\section{REZULTATI I DISKUSIJA}

Specijalizovana laboratorija u Istraživačko Razvojnom Centru IHIS je rezultat višegodišnjeg istraživačkog rada u oblasti zavarivanja i lemljenja. Laboratorija je po strukturi opreme i oblasti rada jedinstvena u Srbiji. Postojeća eksperimentalna oprema uz podršku naučnog i istraživačkog kadra omogućava realizaciju istraživačko razvojnih projekata, edukaciju tehničkog kadra i predstavlja stručno i naučno jezgro sposobno da pruži stručnu podršku i domaću tehnologiju budućim industrijskim kapacitetima za proizvodnju dodatnih materijala za zavarivanje u Srbiji.

Eksperimentalna oprema, primenjeni tehnološki procesi zbog različitih oblasti mašinstva, metalurgije i tehnologije pored razvoja dodatnih i pomoćnih materijala za zavarivanje čelika i obojenih metala i legura, pruža realne mogućnost za praktičnu edukaciju visokoobrazovanog tehničkog kadra .

Međutim, evidentno je da nedostaju određeni delovi tehnološke opreme zbog čega se pojedine tehnološke operacije kao što je višestepeno izvlačenje, ravnanje i sečenje žice za izradu jezgra elektrode izvodi kod kooperanta. Nedostaje značajan do ispitivačke opreme koja bi pratila kvalitet nove šarže dodatnog materijala $u$ pogledu hemijskog sastava i mehaničkih osobina metala šava što angažovanjem kooperanta usporava rad.

\section{RESULTS AND DISCUSSION}

The specialized laboratory in the Research and Development Center IHIS is the result of years of research in the field of welding and soldering. The laboratory, with its structure of equipment and field of work is unique in Serbia. The existing experimental equipment with the support of scientific and research personnel enables the completion of research and development projects, training of technical staff and represents the professional and scientific nucleus able to provide professional support and local technology to future industrial plants for production of welding consumables in Serbia.

The experimental equipment, applied technological processes due to various fields of mechanical engineering, metallurgy and technology in addition to the development of fillers and auxiliary materials for welding steel and non-ferrous metals and alloys, provides real opportunities for practical training of highly educated technical staff.

However, it is evident that there is a of lack certain parts of the technological equipment so, certain individual operations such as multiple-drawing, straightening and cutting wire for making the core of the electrode are subcontracted. An important part of the surveying equipment is missing that would monitor the quality of the new batch of fillers regarding chemical composition and mechanical properties of the weld metal and hiring subcontractors slows down the process. 


\section{ZAKLJUČCI}

Eksperimentalna oprema u Istraživačko Razojnom Centru IHIS pretstavlja veoma značajnu osnovu za razvoj i uvođenje u proizvodnju novih dodatnih i pomoćnh materijali za zavarivanje i lemljenje. Tehnološka oprema je namenjena za određenu vrstu proizvoda (punjena žica, obložena elektroda) ali je univerzalna u pogledu vrste materijala od kojih se prave novi proizvodi (železo i legure železa zatim bakar i Culegure, alumnijum i Al-legura, titan i Ti-legure i drugi konstrukcioni materijali) koji po osobinama i kvalitetu prate razvoj osnovnih materijala.

Eksperimentalna oprema ne poseduje visok proizvodni kapacitet zbog čega pod određenim uslovima može da preraste u proizvodno odelenje za izradu specijalnih visokolegiranih dodatnih materijala za zavarivanje i navarivanje. Specijalizovana laboratorija u Istraživačko Razojnom Centru IHIS Beogrd je otvorena za saradnju na razvoju dodatnih i pomoćnih materijala za zavarivanje i lemljenje svih kvaliteta osnovnih konstrukcionih materijala kao i za sručno usavršavanje tehničkog kadra.

\section{ZAHVALNOST}

Ovaj rad je podržan od strane Ministarstva za obrazovanje, nauku i tehnološki razvoj Republike Srbije (broj projekta TP34016 "Razvoj tehnologije izrade obloge i jezgra na bazi domaćih sirovina za prizvodnju specijalnih obloženih elektroda namenjenih za elektrolučno zavarivanje čelika ")

\section{REFERENCE}

[1] N. Bajić, M. Mrdak, S. Stojadinović, J. Pekez, Z. Karastojković, M. Rakin, D. Veljić: Mastering production of coated electrodes with a cored wire core, The $45^{\text {th }}$ International October Conference on Mining and Metallurgy, 2013, Bor Lake, Bor (Serbia)

[2] N. Bajić, S. Stojadinović and J. Pekez: Welded Joints Testing Obtained by Application of Full and Activated Electrode, Journal of Materials Science and Engineering A 3 (5) (2013) 334337.

[3] N. Bajić, D. Veljić, M. Rakin, S. Stojadinović, J. Pekez, M. Mrdak: Mastering of production of flux-cored wires intended for wide layer surfacing using the EPP- procedure, The $45^{\text {th }}$ International October Conference on Mining and Metallurgy, 2013, Bor Lake, Bor (Serbia)

[4] N.N. Potapov, D. N. Baranov, O. S. Kakovkin, D. B. Vitman i dr.: Svaročnie provoloki i elektrodi, ISBN 5-217-01236-8., Moskva, Mašinostrenie, 1993.

[5] N. Bajić, M. Simičić, B. Bobić, D. Veljić, B. Petrovski: Analysys of influence of filler metal composition on the quality of welded joints of micro-alloyed, II Međunarodnom Kongresu „Inženjerstvo, ekologija i materijali u procesnoj industriji“, B i H, Jahorina, 2011, str. 1164-1175.

\section{CONCLUSION}

The experimental equipment in the Research and Development Center IHIS represents an important basis for the development and introduction into production of new fillers and auxiliary materials for welding and soldering. The technological equipment is designed for a specific type of product (cored wire, coated electrodes) but is universal in terms of the type of material used to make new products (iron and iron alloys then copper and Cu-alloys, aluminum and Al-alloys, titanium and Tialloys and other construction materials), which according to the characteristics and quality reflect the development of the basic materials.

The experimental equipment does not have high production capacity therefore under certain conditions can become a productive department for production of special high alloy welding and surfacing consumables. The specialized laboratory in the Research and Development Center IHIS Belgrade is open for cooperation on the development of fillers and auxiliary materials for welding and soldering of all qualities of basic construction materials as well as expert training of technical personnel.

\section{ACKNOWLEDGEMENTS}

This paper is supported by the Serbian Ministry of Education, Science and Technological Development (project number TR34016 "Development of covering and core production technology based on local raw materials for manufacturing of special coated electrodes designed for steel arc welding"

[6] N Bajic., V. Sijacki-Zeravcić., B. Bobic, D. Cikara, M. Arsić: Filler Metal Influence on Weld Metal Structure of Micro-Alloyed Steel, Welding Journal, Supplement Vol.90 (2011) 55-62.

[7] N. Bajić, B. Petrovski, B. Bogdanović, M. Rakin: "Development of a device for semi-industrial production of cored filer wires“, Inženjerstvo, materijali i menadžment u procesnoj industriji, Jahorina- Republika Srpska, oktobar 2009, IT47, str.280-283.

[8] N. Bajić., S. Stojadinović, M. Rakin: The application of flux cored wire for welding on the surface of operating parts of agricultural achines, Tractors and power machines, Scientific paper, UDK: 631.372 Biblid: 03549496(2005) 10:4, p.I09-114.

[9] N. Bajić, M. Rakin, S. Stojadinović: Surfacing of the worn part of crane wheel with flux cored wire, Zavarivanje i zavarene konstrukcije, UDK/UDC:621.791, ISSN 0354-7965,Beograd (4/2006), str.147-150.

[10] N. Bajić, S. Stojadinović, J. Pekez: Full and fluxcored activated wire application for arc welding of low carbon steel in $\mathrm{CO}_{2}$ and $\mathrm{CO}_{2}$ gas mixtures, Jurnal for Scientists and Engineers, ISSN 1451-9070, No 7, br. 1, 2010. 